\title{
HOW (NOT) TO TALK ABOUT ABORTION
}

\author{
Meredith Johnson Harbach *
}

\author{
"Respect, Mr. Speaker, is due to those on both sides of \\ every issue."
}

-Delegate Kathy J. Byron (R-Bedford, VA)

In the spring of 2012, abortion politics dominated much of our public discourse, with rhetoric heating, tempers flaring, and television satirists salivating. ${ }^{2}$

The Virginia General Assembly was right in the middle of the fray. The most controversial legislation included a bill requiring women to submit to an ultrasound before receiving an abortion, ${ }^{3}$ a "personhood" bill that defined the beginning of life as conception, ${ }^{4}$

\footnotetext{
* Assistant Professor of Law, University of Richmond School of Law. I owe a special debt of gratitude to my students in the inaugural semester of UR's "Regulating Reproduction" seminar for their intellectual friendship and for their willingness to create a rigorous, engaged, and respectful community: Maggie Bowman, Meghan Casey, David Crumplar, Katherine Cumpton, Catherine Gill, Megan Hazlett, Dori Martin, Michelle Miller, Angela Neiman, Sara Nunley, Rachel Reynolds, Jhontera Rivers, Amy Travin, Amy Weiss, and Rachel Yates. I also thank Tara Casey, David Harbach, Corinna Lain, Carl Tobias, Kevin Walsh, and Amy Weiss for their helpful reactions and comments on the piece. And finally, I thank Amy Weiss for her terrific research assistance.

1. The Family Foundation, Pro-Life Floor Speech-Delegate Kathy Byron, YouTUBE (Mar. 7, 2012), http://www.youtube.com/watch?v=McT5BgB8Bn0 [hereinafter Pro-Life Floor Speech]. Delegate Byron made this statement in the context of a speech in which she described the "vile, crude, disrespectful, and frequently obscene messages" she and other supporters of the mandatory ultrasound bill received from opponents of the bill. Id.

2. At the national level, the Obama administration's requirement that health insur ance cover contraception took center stage. See, e.g., Obama Announces Change in Contraceptive Coverage Rule After Outcry, FoxNews (Feb. 10, 2012), http://www.foxnews.com/pol itics/2012/02/10/white-house-to-announce-accommodation-on-contraceptive-policy/. At the state level, forty-five of the forty-six legislatures that convened in Spring 2012 introduced more than 900 measures related to reproductive rights and reproductive health. See State Policy Trends: Abortion \& Contraception in the Crosshairs, GUTTMACHER INST. (Apr. 13, 2012), http:/www.guttmacher.org/media/inthenews/2012/04/13/index.html [hereinafter State Policy Trends].
}

3. H.B. 462, Va. Gen. Assembly (Reg. Sess. 2012).

4. H.B. 1, Va. Gen. Assembly (Reg. Sess. 2012). 
and a measure that would have withdrawn state public assistance funds for poor women seeking abortions because of "gross and totally incapacitating" deformities or deficiencies. ${ }^{5}$ After protracted wrangling over whether the mandatory ultrasound requirement would include transvaginal ultrasounds, ${ }^{6}$ the bill that ultimately was signed into law requires transabdominal ultrasounds, but allows women to refuse consent to transvaginal ones. ${ }^{7}$ The personhood bill was carried over to the 2013 session, $^{8}$ and the abortion funding measure was passed over indefinitely in the senate. ${ }^{9}$

5. H.B. 62, Va. Gen. Assembly (Reg. Sess. 2012) (proposing repeal of VA. CoDE ANN. $\S 32.1-92.2$ (Repl. Vol. 2011)). These measures prompted more than 1000 protestors to travel to the state Capitol and voice their disagreement. See, e.g., Chelyen Davis, Women Hold Capitol Protest, FREE LANCE-STAR (Feb. 21, 2012), http://fredericksburg.com/News/ FLS/2012/022012/02212012/684387. Eventually, opponents of these measures delivered petitions with 33,000 signatures to Governor Bob McDonnell's office. Harry Minium, ProChoice Groups Deliver Petitions to Gov. McDonnell, VIRGINIAN-PILOT (Feb. 22, 2012), http:/www.hamptonroads.com/2012/02/prochoice-groups-deliver-petitions-gov-mcdonnell. Later in the spring, police in riot gear arrested thirty protestors in front of the Capitol. See Video: Abortion Rights Protesters Clash with Police at Virginia Capitol, CBS DC (Mar. 5, 2012), http://washington.cbslocal.com/2012/03/05/video-abortion-rights-protesters-clashwith-police-at-virginia-capitol/.

6. See Wesley P. Hester \& Jim Nolan, A Restless Session of Rancor; Contentious Social Legislation Fueled Protests, Partisanship, RICH. Times-DispatCH, Apr. 9, 2012, at A1. A compromise was reached at the urging of Governor McDonnell who, after public outcry, issued a statement on February 22, 2012, stating that " $[\mathrm{m}]$ andating an invasive procedure in order to give informed consent is not a proper role for the state. No person should be directed to undergo an invasive procedure by the state, without their consent, as a precondition to another medical procedure." Press Release, Office of the Governor, Statement of Governor Bob McDonnell on SB 484 (Feb. 22, 2012), available at http://www.governor,vir ginia.gov/News/viewRelease.cfm?id=1148.

7. The final version of the bill includes an exemption for victims of rape and incest, if the incident was reported to law enforcement authorities. H.B. 462, Va. Gen. Assembly (Reg. Sess. 2012) (enacted as Act of Mar. 7, 2012, ch. 131, 2012 Va. Acts __). Further, women who live one hundred miles or more from an abortion facility may have a mandatory ultrasound only two hours before the procedure rather than twenty-four. Id. Also, physicians need not obtain the patient's informed written consent if the abortion is performed pursuant to a medical emergency or spontaneous miscarriage. Id.

Interestingly, Governor McDonnell appeared to be persuaded, in part, by the conservative Rutherford Institute, one of the principal architects of Delegate Marshall's "personhood" bill. See Letter from John W. Whitehead, Founder and President, The Rutherford Inst., to Robert F. McDonnell, Governor, Va., (Feb. 20, 2012), available at https://www, rutherford.org/files_images/general/2-20-12_Letter_HB_462.pdf.

8. See Jim Nolan, Senate Scraps "Personhood" Bill, RICH. TImes-DisPatCH, Feb. 24, 2012 , at $\mathrm{A} 1$.

9. See Mark L. Cole, H.B. 62, Abortion Funding; Repealed, VA. LEGiSLative InFo. SYS., http://lis.virginia.gov/cgi-bin/legp604.exe?ses=121\&typ=bil\&val=hb62. Less remarked upon was an amendment to Virginia's wrongful death statute that allows women to bring wrongful death actions on behalf of fetuses. Act of Apr. 9, 2012, ch. 725, $2012 \mathrm{Va}$. Acts (codified as amended at VA. CODE ANN. $\S 8.01-50$ (Cum. Supp. 2012)). Several 
Along the way, Virginia found itself in the national spotlight, lambasted on The Daily Show with John Stewart and Saturday Night Live. ${ }^{10}$ But rhetoric used at the Capitol was anything but funny. Legislative attempts at humor fell decidedly flat, both with other lawmakers and with the Virginia public. Many were embarrassed by the negative attention Virginia received. ${ }^{11}$ Others were troubled and offended by the tenor of the debate over these issues at the General Assembly. ${ }^{2}$ And the glib comments of some in the General Assembly belied the serious nature of the debated legislation and its consequences. ${ }^{13}$

Through the thick of this debate, I was part of a much richer conversation in a small classroom here at the University of Richmond School of Law, where I was teaching a seminar: Regulating Reproduction. Throughout the semester, our class engaged in a thoughtful, rigorous, and respectful conversation about the very same issues the General Assembly considered.

other abortion-related measures failed to become law, including several measures that would have prohibited health insurance coverage for abortions, the "Virginia Pain-Capable Unborn Child Protection Act," and a House measure to repeal Virginia's mandatory HPV vaccine requirement for girls entering the sixth grade. See H.B. 464, Va. Gen. Assembly (Reg. Sess. 2012) (prohibiting abortion coverage); S.B. 496, Va. Gen. Assembly (Reg. Sess. 2012) (same); H.B. 1285, Va. Gen. Assembly (Reg. Sess. 2012) (Virginia Pain-Capable Unborn Child Protection Act); S.B. 637, Va. Gen. Assembly (Reg. Sess. 2012) (same); H.B. 1112, Va. Gen. Assembly (Reg. Sess. 2012) (repealing HPV vaccination requirement).

10. See Hester \& Nolan, supra note 6. Former Governor Tim Kaine complained that legislators had created "fodder for late night comedy shows and [had] turned Virginia into a laughing stock." Minium, supra note 5 (internal quotation marks omitted).

What follows is a sampling of the television humor. John Stewart on The Daily Show: "Oh man, Transvaginal Ultrasound? The fifteen-member jazz-fusion chorus band? Those guys are awesome! I saw them at the Beacon in '94; they were amazing! Transvaginal U1trasound, Transvaginal Ultrasound. Wait a minute. Oh, not the band. The other one with the wand and the hoo-hoo?" Punanny State-Virginia's Transvaginal Ultrasound Bill, THE DAILY SHOW WITH JON STEWART (Feb. 21, 2012), http://www.thedailyshow.com/watch/tuefebruary-21-2012/punanny-state-.-virginia-s-transvaginal-ultrasound-bill. On Saturday Night Live, Amy Poehler quipped, "I love Transvaginal. It's my favorite airline. I got so many miles on Transvaginal that I always get upgraded to Lady Business." Really? with Seth and Amy: Birth Control, NBC.COM (Feb. 19, 2012), http://www.nbc.com/saturdaynight-live/video/really-with-seth-and-amy-birth-control/1386256.

11. Ginny Brock, Editorial, An Indecent Proposal, RoANoke TIMES, Feb. 27, 2012, at A11 ("As a Virginian, I am embarrassed and sad that my state with its history of sound thinking is being dragged through the late-night comedy shows, a subject of ridicule. I am dismayed at the low caliber of politician this state has seen fit to elect in recent years.").

12. See, e.g., Tara Casey, What I Have Learned Today, RVA MAG. (Mar. 1, 2012), http://rvamag.com/articles/full/14008/what-i-have-learned-today ("I learned that the flip phrases 'jelly on the belly' and 'abortion is a matter of lifestyle convenience,' which I personally heard in the halls of my state legislature, translate to actual votes and platform positions of disengaged legislators.").

13. See, e.g., id. 
In this essay, I aim to have a conversation about how we converse-how we talk-about abortion and related issues. In the process, I want to consider how we might come together to discover issues of shared commitment and values and transform the existing abortion debate. I begin with a review of some of the more notable abortion-related rhetoric during the 2012 Virginia General Assembly, and contrast that rhetoric with the discourse in my classroom. I then consider whether and how we might move forward together toward a more meaningful and productive dialogue on these issues.

Talking about abortion is hard. Striking the right tone on an issue about which convictions are so deeply held is especially challenging. My point here isn't to change minds or to pretend at agreement where it doesn't exist. What I do hope to do, however, is to consider whether changing our approach to abortion discourse-whether in the legislature or in the classroom-might lead us away from polarization and gridlock, and toward civility and common ground.

\section{ABORtion TALK IN THE GENERAL ASSEMBLY}

"Can we dial down the rhetoric ...?"

-Delegate Jennifer McClellan (D-Richmond) ${ }^{14}$

The mandatory ultrasound bill proved to be the rhetorical lightning rod for Virginia's 2012 session..$^{25}$ The measure's proponents argued that the bill was central to informed consent for women seeking to have abortions. ${ }^{16}$ Critics maintained that it unnecessarily interfered with the patient-physician relationship and was an attempt to shame women and dissuade them from having abortions. ${ }^{17}$

14. See Laura Vozzella \& Anita Kumar, Richmond Wades Through 'Crossover Day', WASH. POST (Feb. 14, 2012), http://www.washingtonpost.com/local/dc-politics/richmondwades-through-crossover-day/2012/02/14/gIQAphyhER_story.html (quoting Del. McClellan's plea on Twitter) (internal quotation marks omitted).

15. See Jim Nolan, At Sponsor's Urging, Senate Scraps Abortion Ultrasound Bill, RICH. TIMES-DISPATCH, Feb. 24, 2012, http://www2.timesdispatch.com/news/2012/feb/24/8/ senate-adjourns-tor-day-without-taking-up-abortion-ar-1713430/; Bob Lewis, Va. House Scraps Invasive Pre-Abortion Requirement, Associated PRESs ST. \& LOC. WIRE, Feb. 23, 2012.

16. See Nolan, supra note 15.

17. See id. 
How did our legislators talk about abortion? Abortion talk in the General Assembly was troubling on multiple levels. Some comments and rhetoric were disrespectful and dismissive of wom. en's life experiences. Others were inappropriate attempts at humor that trivialized the issues and had concerning undertones of bias. Finally, in addition to the substance of these comments, at times the actual words legislators used to advance their agendas were unprofessional, inappropriate, and offensive.

A number of comments disregarded the realities of women's situations and experiences. Some commentary was disrespectful of the many women-about half of American women by age fortyfive-who have an unintended pregnancy. ${ }^{18}$ For example, during early floor debate on the mandatory ultrasound requirement, Delegate C. Todd Gilbert (R-Shenandoah) characterized most abortions as "matters of lifestyle convenience."19 In fact, threefourths of women who have abortions are concerned about their responsibilities to other individuals; "three-fourths say they cannot afford a child; three-fourths say that having a baby would interfere with work, school, or the ability to care for dependents; and half say they do not want to be a single parent or are having problems with their husband or partner."20 These are hardly matters of mere "convenience," and later in the day, Delegate Gilbert apologized for his comments. ${ }^{21}$

Other comments dismissed the importance of women's consent and their bodily integrity. For example, while debating mandatory transvaginal ultrasounds, one Republican legislator reportedly

18. Abortion in the United States: Quick Stats, GUTTMACHER INST., http://guttma cher.org/media/presskits/abortion-US/statsandfacts.html (last visited Oct. 15, 2012).

19. HuffPostPolitics, Virginia Lawmaker C. Todd Gilbert Calls Abortion a "Lifestyle Convenience," YouTUBE (Feb. 14, 2012), http://www.youtube.com/watch?v=Uci-a6wAHzY; see also Anita Kumar, Del. Gilbert Says He Regrets' Comments on Abortion, WASH. POST (Feb. 14, 2012, 07:56 PM ET), http://www.washingtonpost.com/blogs/virginia-politics/post/ del-gilbert/says/he/regrets/comments-on-abortion/2012/02/14/gIQAEG1VER_blog.html.

20. See Facts on Induced Abortion in the United States, GUTTMACHER INST., (Aug. 2011), http://www.guttmacher.org/pubs/fb_induced_abortion.pdf [hereinafter Facts on Induced Abortion].

21. Kumar, supra note 19. In a statement, Delegate Gilbert said, Abortion is a sad and deeply serious occurrence. ... Individuals on both sides of this issue agree that it is tragic for all involved. I recognize that few women undergo the procedure lightly. It leaves scars, both mental and physical, that can last forever. I regret that my comments earlier today on the House floor were insensitive to that reality.

Id. (internal quotation marks omitted). 
commented that women already had made the decision to be "vaginally penetrated when they got pregnant."2 Similarly, Delegate Kathy J. Byron (R-Bedford) compared a transvaginal ultrasound to a standard gynecological exam with a speculum; she ar. gued that an abortion was, in fact, much more invasive than a mandatory ultrasound. ${ }^{23}$ These comments overlooked a crucial distinction between mandatory ultrasounds and voluntary intercourse or medical procedures: the woman's consent. ${ }^{24}$

Democrats seized on the consent issue but also overplayed their rhetorical hand, glossing over women's lived experiences. Delegate Lionel Spruill (D-Chesapeake) and other Democrats likened the mandated test to rape, an argument that reverberated among activists, the media, and the blogosphere. ${ }^{25}$ This rhetoric disregarded the difference between a medical test performed in the safety of a physician's office without fear of violence on the one hand, and a violent sexual assault on the other. ${ }^{26}$

Other lawmakers made unprofessional and failed attempts at humor during the debate. In the midst of the contentious manda-

22. Jessica Valenti, Editorial, A War on Women; Latest Paternalistic Efforts to Control Female Sexuality Are Part of a Long Pattern, BALT. SUN, Feb. 29, 2012, at 17A (internal quotation marks omitted). This comment was relayed by Delegate David Englin (DAlexandria). Id.

23. StopTheWarOnWomen, Debate on Amendments to Ultrasound Bill, YouTUBE (Feb. 26, 2012), http://www.youtube.com/watch?v=z-YuZUZyki8.

24. In attempt to highlight the actual consequences of a mandatory ultrasound bill for women, one legislator sought to impose similar requirements for men: Senator Janet Howell (D-Fairfax) attached an amendment to the ultrasound bill that would have required men to have a rectal exam and a cardiac street test before obtaining a prescription for erectile dysfunction medication. Laura Vozzella \& Anita Kumar, Va. GOP Crams in Social Agenda, WASH. PosT, Feb. 4, 2012, at A01.

25. Harry Minium, General Assembly Pre-Abortion Ultrasound Might Be Made Optional, VIRGINIAN.PILOT, Feb. 22, 2012, at B1; see Julian Walker \& Harry Minium, Senate Passes, McDonnell to Sign Abortion Bill, VIRGINIAN-PILOT, Feb. 29, 2012, at A1; Laura Vozzella \& Anita Kumar, In Va. Nitty-Gritty Knocks Abortion Bill off Fast Track, WASH. PosT, Feb. 24, 2012, at A01; see, e.g., Dahlia Lithwick, Virginia's Proposed Ultrasound Law Is an Abomination, SLATE (Feb. 16, 2012), http://www.slate.com/articles/double $\mathrm{x} /$ doublex/2012/02/virginia_ultrasound_law_women_who_want_an_abortion_will_be_forcibly _penetrated_for_no_medical_reason.html.

26. Delegate Bob Marshall (R-Prince William) responded to this "haranguing" and warned about "what happens to us in the next life" when he noted that Planned Parenthood and other "so-called clinics that perform abortions" don't call ultrasounds "rapes" when they describe typical abortion procedures. Bob Marshall, Delegate Marshall Discusses What Planned Parenthood Says About Ultrasounds, YouTUBE (Feb. 23, 2012), http://www.youtube.com/watch?v=wH9-bCG7x1M; Harry Minium \& Michael Sluss, Abortion Bill Falters As Gov. Backs Away General Assembly, VIRGINIAN-PILOT, Feb. 23, 2012 at $\mathrm{A} 1$. Yet Delegate Marshall, too, disregarded the distinction between voluntary ultrasounds and state-mandated ones. 
tory ultrasound debate, Delegate David Albo (R-Fairfax) told a "surprisingly ribald" story about his thwarted attempt at seducing his wife, complete with "the music of a classic boom-chickawah-wah riff." ${ }^{27}$ According to Delegate Albo, while trying to set up a seduction scene with his wife the night before, he inadvertently landed on the Rachel Maddow Show while searching for the Washington Redskins. ${ }^{28}$ After watching Delegate David Englin's (D-Alexandria) criticism of the mandatory ultrasound bill on the Maddow Show, Delegate Albo's wife said, "I gotta go to bed."29 Delegate Albo delivered the speech amidst laughter in the chamber, some genuine and some seemingly uncomfortable.$^{30}$ Broader reaction was not quite as sanguine ${ }^{31}$ Many thought the awkward joke trivialized the significance and terms of the debate. ${ }^{32}$

In another feeble attempt at humor, Delegate Bob Marshall (RPrince William) tried to respond to Saturday Night Live's ribbing of the Virginia General Assembly in kind. In a television interview, Delegate Marshall decried the "rampant sexist nature" of "that chauvinist Seth [Meyers's]" effrontery in commenting on pregnancy, "when in fact, it should have been Baby Momma.",33 Despite Delegate Marshall's apparent "awkward attempt to sound hip," ${ }^{34}$ his use of controversial, sometimes-offensive slang in reference to pregnant women and mothers was unfortunate. The term "baby momma" is widely understood to refer to an unmarried pregnant woman or mother, who may or may not have a rela-

27. The Reliable Source, Del. Dave Albo: All that Ultrasound Talk Ruined a Romantic Night (Video), WASH. Post (Feb. 24, 2012), http://www.washingtonpost.com/blogs/reliable source/post/del-albo-all-that-ultrasound-talk-ruined-a-romantic-night-video/2012/02/24/g IQAil9WYR_blog.html.

28. Not Larry Sabato, Dave Albo's Wife Rejects Sex with Him, YouTUBE (Feb. 24, 2012), http://www.youtube.com/watch?v=vbLsy9eKBlI.

29. Id.

30. See id.

31. See, e.g., Tamara Dietrich, Opinion, Virginia Women Striking Back, DaILy PrEsS, Mar. 9, 2012, at A1.

32. Yet despite the delegate's strong support of mandatory ultrasound-including the transvaginal ultrasound requirement-he couldn't bring himself to actually use the word "transvaginal," instead referring to "trans-v this' and 'trans-v that." See Dietrich, supra note 31 .

33. Perry Stein, Morning Read: VA Delegate's Comedic Response to SNL Skit, NBCWASHINGTON.COM (Feb. 21, 2012), http://www.nbcwashington.com/blogs/first-readdmv/Morning-Read-VA-Delegates-Comedic-Response-To-SNL-Skit-139809283.html.

34. State v. Harris, 2009 Wisc. App. LEXIS 39 , at ${ }^{\star 22}$ (unpublished opinion), rev'd, 786 N.W.2d 409 (Wis. 2010). Several years ago, a state trial judge in Wisconsin similarly found his usage of the term under scrutiny with the sentencing of an African American defendant. See id. 
tionship with the fetus's or child's father. ${ }^{35}$ The term often evokes racial stereotypes. ${ }^{36}$ Marshall's comment suggested a lack of respect for struggling pregnant women and mothers. ${ }^{37}$

Finally, as the debate continued to intensify, it took on an angrier tone, with the words themselves becoming increasingly unseemly. ${ }^{38}$ For example, Senator Louise Lucas (D-Portsmouth) joined the fracas, quoting John Stewart's lewd slang for female sex organs..$^{39}$ The rhetoric outside legislative chambers also became heated. Delegate Byron described to her colleagues the "vile, crude, disrespectful, and frequently obscene messages" she and supporters of the transvaginal ultrasound bill received from the bill's opponents. ${ }^{40}$ Especially troubling, some members of the public "readily and quite casually suggested methods by which [the delegates] should die and openly expressed their desire that [their] deaths be hastened."

And so it was with the General Assembly's "raucous legislative squabble over abortion restrictions." ${ }^{42}$ One political scientist said

35. Harris, 786 N.W.2d at 421.

36. Id.

37. In fact, according to the Guttmacher Institute, "Women who have never married and are not cohabitating" account for less than half of all abortions. See Facts on Induced Abortion, supra note 20.

38. Bob Lewis, Ire Flashes over Va. Protest, Police Response, Associated Press St. \& LOC. WIRE, Mar. 6, 2012 (describing "locker-room language").

39. "Virginia used to be synonymous with results: business, growth, solid management. Now, we're the transvaginal ultrasound state, otherwise called 'Punanny State,' where peaceful protesters wind up in jail." Id. (internal quotation marks omitted); Bob Lewis, Session Dismissed Gov's Overreach, Obstruct Advice, Associated PREss ST. \& Loc. WIRE, Mar. 11, 2012.

40. Pro-Life Floor Speech, supra note 1. No doubt some of the messages were among those characterized as "sarcasm bomb[s]." Cf. Amy Bingham, Rick Perry's FB Page 'Bombed' with Questions About 'Lady Parts', ABC NEws (Mar. 21, 2012, 1:55 PM), http:/l abcnews.go.com/blogs/politics/2012/03/protesters-inundate-rick-perrys-facebook-page-withcoy-questions-about-their-lady-parts/. As described by the Washington Post, in the wake of the ultrasound bill's passage, opponents of the bill flooded GOP Facebook pages "with the kind of information normally reserved for the ob/gyn." Laura Vozzella, 'Lady Business' Activism Floods Va. Republicans' Facebook Pages, Wash. Post (Mar. 15, 2012, 10:00 AM), http://www.washingtonpost.com/blogs/virginia-politics/post/lady-business-activism-floodsva-republicans-facebook-pages/2012/03/15/gIQAm8A8DS_blog.html.

41. Pro-Life Floor Speech, supra note 1.

42. Lewis, supra note 38 . One observer summed up Virginia's 2012 General Assembly this way:

More than 1,000 women locked arm-in-arm in silent protest. Police in riot gear confronting women's-rights demonstrators on the Capitol steps. Virginia being skewered over vaginal ultrasounds on "The Daily Show With Jon Stewart." These are the abiding images from the 60-day regular session of the 2012 General Assembly .... Legislators passed more than 1,500 bills, but 
he hadn't seen so much tumult in Richmond since the civil rights and Vietnam War protests. ${ }^{43}$ But the tone-if not the terms-of the debate might have been different. I turn now to contrast the General Assembly's legislative clashes with law students' discussion of the same issues in the classroom.

\section{Abortion Talk in the ClassRoom}

"II]t is so important to remain sensitive when speaking about the topic. It in no way changes my views, but it is important to speak in a loving and gracious tone rather than an air of condem. nation."

-University of Richmond Law Student, Regulating Reproduction Seminar, Spring $2012^{44}$

In contrast to the angry discourse frequently present in the General Assembly, this student's comment reflects the students' ethos in our Spring 2012 Regulating Reproduction seminar. The goal of the course was to develop students' understanding of the interrelationship of legal rules, politics, ideology, and socioeconomic realities that shape reproductive rights and justice. As part of our exploration of "reproductive rights" and "reproductive justice," we considered a broad spectrum of related topics, including types of abortion restrictions upheld since Roe $v$. Wade $e^{45}$ and Planned Parenthood v. Casey, ${ }^{46}$ access to contraception and reproductive health services, new reproductive technologies, and the federal government's role in reproductive rights, among others.

none attracted as much attention as those mandating invasive pre-abortion ultrasound exams, something its most strident critics called "state-sponsored rape." The measure prompted protests on Capitol Square, including one that resulted in 30 arrests. It drew scorn from national columnists and television comedians and generated some of the sharpest rhetoric in a long time on the Senate and House of Delegates floors.

Larry O'Dell \& Bob Lewis, Abortion Bill Stole Show at 2012 General Assembly, Associated PREss St. \& LoC. WIRE, Mar. 11, 2012.

43. Wesley P. Hester \& Jim Nolan, A Restless Session of Rancor; Contentious Social Legislation Fueled Protects, Partisanship, Rich. TIMES-DisPaTCH, Apr. 9, 2012, at A1 (referring to a statement from University of Virginia political scientist Larry Sabato).

44. Student Comment, Regulating Reproduction Discussion Questions, Class 6, at 4-5 (Feb. 13, 2012, 9:01 PM) (on file with author).

45. 410 U.S. 113 (1973).

46. 505 U.S. 833 (1992). 
As we began the semester, I emphasized that the topics we'd be exploring would be dynamic, controversial, and often deeply personal. I asked that the students maintain an atmosphere of professionalism at all times, according respect and sensitivity to the diverse experiences, backgrounds, and opinions of their peers. Students on all sides of these difficult issues exceeded all expectations.

How did the students talk about abortion? Rather than dismissing women's lives and experiences, they were eager to explore the real-world circumstances of men and women. They were respectful of the situations that lead women and their families to consider abortion. Rather than understanding abortion as a "lifestyle convenience," one student observed: "I'd like to think that when women go to get an abortion it's something they've agonized over ....,"47

Rather than comparing mandatory ultrasounds to voluntary sex, well-woman exams, or rape, the students were interested in the actual motivations and effects of mandatory ultrasound laws. An example:

The Post-Abortion Syndrome article we read dealt with the psychological effects of having an abortion and the guilty feelings afterward, but what about the psychological effects of guilting someone into having a baby through descriptions of the child's characteristics, colored pictures, and sonograms? Is it not just as likely that having an unwanted child would have severe psychological effects on a woman and her mental health ? $^{48}$

And others: "If ultrasound images and heartbeats are "information' to a person without medical training, [is it] solely that they offer an emotional guide to a woman who may have minimized the humanity and personhood of [her] fetus[?]" "Do the motivations behind [exceptions to mandatory ultrasound laws for minors or victims of rape] deal with emotional trauma this procedure might cause?" ${ }^{\prime 00}$ And finally, "If 'encouraging' more women to

47. Student Comment, Regulating Reproduction Discussion Questions, Class 8, at 5 (Feb. 27, 2012, 8:59 PM) (on file with author).

48. Student Comment, Regulating Reproduction Discussion Questions, Class 8, at 2 (Feb. 28, 2012, 8:45 AM) (on file with author).

49. Student Comment, Regulating Reproduction Discussion Questions, Class 8, at 1-2 (Feb. 28, 2012, 8:58 AM) (on file with author).

50. Student Comment, Regulating Reproduction Discussion Questions, Class 8, at 2 (Feb. 28, 2012, 8:48 AM) (on file with author). 
be mothers is an objective of mandatory sonogram statute[s], should men be required to view sonograms, for the purpose of 'encouraging' men to be fathers?"51

Unlike some Virginia legislators, the students understood that topics we were exploring had real consequences for real people. Although the dynamic in the classroom was at times lighthearted, the students never made light of the serious topics with which we grappled and were always respectful of other points of view, even when they disagreed. Here's one illustrative comment by a prolife student, who was assiduously respectful of her classmates: "I was not quite aware of the measures women took with their own bodies to terminate their pregnancies when legal abortions are not accessible. This was one of the more compelling arguments I've read that made me consider the negative implications of prohibiting abortion." ${ }^{.52}$

Finally, the students understood the importance of rhetoric and tone in our conversations about abortion. One student's recognition of the importance of speaking in a "loving and gracious tone rather than an air of condemnation" is a commendable example of this. ${ }^{53}$ Another student turned her critical eye to an author's choice of rhetoric and tone in a scholarly article we studied: "Is [the author's] article really effective, or do her style, inflammatory tone and jumps in logic take away from her message?"54

In sum, the students' approach to our study and debate of these topics was a commendable antidote to the Virginia legislature's toxicity. Rather than dismissing real experiences and consequences, they sought to dig deep. Rather than trivializing issues with sarcasm and jokes, they approached our studies earnestly and conscientiously. And rather than using words that alienated and offended, they chose their words carefully. Using these experiences as an alternative model for talking about these vexed issues, I now consider the larger lessons we can draw, and how we might move forward.

51. Student Comment, Regulating Reproduction Discussion Questions, Class 8, at 1 (Feb. 28, 2012, 9:12 AM) (on file with author).

52. Student Comment, Regulating Reproduction Discussion Questions, Class 5, at 4 (Feb. 6, 2012, 9:10 PM) (on file with author).

53. Student Comment, Regulating Reproduction Discussion Questions, Class 6, at 4-5 (Feb. 13, 2012, 9:01 PM) (on file with author).

54. Student Comment, Regulating Reproduction Discussion Questions, Class 4, at 3 (Jan. 31, 2012, 7:47 AM) (on file with author). 


\section{MOVING FoRWARD WITH MEANINGFUl DIALOGUE AND COMMON GROUND}

"The issue of abortion raises passionate feelings among many Virginians, based on one's own views on life and liberty. While debates in the legislature over the decades may seem to indicate there is no common ground to be found on this issue, I believe that areas of agreement can and do exist."

-Governor Bob McDonnell ${ }^{55}$

If we are to take "areas of agreement" and the pursuit of common ground on abortion seriously as a project, we must find a better way to talk with each other about it. The comparison between the 2012 General Assembly and our experience in the classroom has something to teach us about transcending gridlock and working together. I don't mean to suggest that legislative debate is the same thing as academic discourse. The two forums have different focus, motivations, and consequences. But that's not to say that they do not-or ought not-share common aspirations of civility, greater understanding, and trust, which make constructive conversation and common ground possible.

In fact, there is a successful "common ground" model for approaching the abortion conflict that may change the dynamic of the debate and lead to progress. The Search for Common Ground ("SFCG") is an international non-governmental organization whose mission is to "transform the way the world deals with conflict: away from adversarial approaches, toward cooperative solutions. ${ }^{166}$ From 1993 to 2000, the SFCG sponsored The Common Ground Network for Life and Choice. ${ }^{57}$ The project's goal was

to change the dynamic of the abortion conflict in the United States by changing the stance of the opposing parties, from one defined solely by disagreement and characterized by extreme polarization, to one where strong disagreement is acknowledged but where the parties (1) seek to fully understand the others' positions and beliefs, and

55. Press Release, Office of the Governor, Statement of Governor Bob McDonnell on Signing HB462 (Mar. 7, 2012), available at http://www governor.virginia.gov/news/view Release.cfm?id=1165.

56. See Our Mission \& Vision, SEARCH FOR COMMON GROUND, http://www.sfcg.org/ sfeg/sfcg_mission.html.

57. See The Common Ground Network for Life \& Choice, SEARCH FOR COMMON GrouND, http://www.sfcg.org/programmes/us/us_life.html (hereinafter Common Ground Network). 
the issue; (2) seek and name the existence of overlapping values, goals, beliefs and important interests (the common ground); and (3) consider ways to act jointly to move toward shared goals. ${ }^{58}$

As part of the project, the SFCG identified essential techniques for bringing both sides of the abortion issue into "constructive conversation. ${ }^{159}$ This approach seeks to alter the relationship between opposing camps in order to elevate the level of discourse and facilitate the recognition of commonly held values and commitments. These techniques include dialogue, connective thinking, the sharing of personal experience, and genuine questions. ${ }^{60}$

Dialogue is not the same as debate. Rather than seeking to persuade others of a position, dialogue instead focuses on understanding and being understood. As characterized by the SFCG, it is "a process in which people are asked to respect and acknowledge the humanity of the people present regardless of their points of view." ${ }^{, 11}$ Connective thinking resists undercutting another's position, and instead focuses on instances of resonance, despite disagreement. ${ }^{62}$ Personal experiences are constructive because they invite understanding and empathy. Finally, genuine questions lead to honest inquiry. They are "asked in a spirit of real curiosity and a sincere interest in learning the answers. ${ }^{, 63} \mathrm{Im}$ portantly, common ground isn't the same as compromise. Rather than find a middle position, the common ground approach instead seeks to find instances of genuinely shared values and concerns. ${ }^{64}$

While not explicitly focused on the SFCG's common ground approach, the students in our class used tools of dialogue, connective thinking, personal experiences, and genuine questions in class. Their willingness to take this approach was critical to our ability create an honest, rigorous, and respectful intellectual space for our discussions and to our ability to explore issues of common ground.

Rather than holding rigidly to categorical beliefs or trying to change minds, the students were willing to acknowledge weak-

$\begin{array}{ll}\text { 58. } & I d . \\ 59 . & I d . \\ 60 . & I d . \\ 61 . & I d . \\ 62 . & I d . \\ 63 . & I d . \\ 64 . & I d .\end{array}$ 
nesses and consider the potential contradictions in their own positions. Pro-choice students critiqued mistakes made by the prochoice movement, such as its unfortunate alienation of Norma McCorvey-Jane Roe in Roe $v$. Wade ${ }^{65}$ Others questioned why the choice movement has been reluctant to advocate for substantive pre- and post-abortion counseling. ${ }^{66}$ Another student wondered: "Does 'acknowledging' possible benefits to regulating abortion providers hurt the pro-choice movement?" ${ }^{37}$

The students also explored weaknesses in their own positions and asked genuine questions. One student wondered whether the possibility of fetuses experiencing pain ought not compel prochoice advocates to reevaluate their ideas of "life" and when it begins. ${ }^{68}$ Another considered whether leaving the abortion decision solely with women has "the unintended consequence of 'cementing the notion that men are minor players in the life of a family?" ${ }^{\prime \prime 9}$ One student identified a potential conflict between her prochoice stance and her discomfort with the use of assisted reproductive technologies to make "designer" babies: "If a woman's body is her body and I believe that she should be able to terminate a pregnancy for any reason, why shouldn't she be able to construct a pregnancy for any reason?"?

This willingness to engage in constructive dialogue led to connective thinking and to nuance instead of dogma: "Why isn't [the fact that a person can be 'pro-life' but also 'pro-choice'] discussed more in the media?" "My beliefs aren't in either of those places. Do you think people are so black and white on this issue?" ${ }^{22}$ This

65. See Sam Howe Verhovek, New Twist for a Landmark Case: Roe v. Wade Becomes Roe v. Roe, N.Y. Times, Aug. 12, 1995, at 1.

66. "Why does the choice movement seem to shy away from substantive pre- and postabortion counseling?" Student Comment, Regulating Reproduction Discussion Questions, Class 6, at 5 (Feb. 13, 2012, 4:56 PM) (on file with author).

67. Student Comment, Regulating Reproduction Discussion Questions, Class 9, at 4 (Mar. 12, 2012, 8:36 PM) (on file with author).

68. Student Comment, Regulating Reproduction Discussion Questions, Class 8, at 5 (Feb. 27, 2012, 8:59 PM) (on file with author).

69. Student Comment, Regulating Reproduction Discussion Questions, Class 6, at 3 (Feb. 14, 2012, 3:59 AM) (on file with author).

70. Student Comment, Regulating Reproduction Discussion Questions, Class 11, at 2 (Mar. 27, 2012, 8:09 AM) (on file with author).

71. Student Comment, Regulating Reproduction Discussion Questions, Class 9, at 2-3 (Mar. 12, 2012, 9:19 PM) (on file with author).

72. Student Comment, Regulating Reproduction Discussion Questions, Class 10, at 4 (Mar. 19, 2012, 9:43 PM) (on file with author). 
nuance led, ultimately, to a richer exploration of common ground on a number of hotly contested issues, including coerced contraception, abortion, fathers' rights, fetal pain, informed consent, Plan B for minors, sex education, and counseling before and after abortion. ${ }^{73}$

The common ground approach is an alternative paradigm of what abortion discourse can look like. It involves a willingness to challenge assumptions, to acknowledge weaknesses, to listen, and to understand. When we approach each other respectfully and step away from categorical positions, the conversation begins in earnest, and we have a real chance at charting a constructive path forward. ${ }^{74}$

\section{CONCLUSION}

It will not be long before the Virginia legislature revisits abortion legislation. The issue remains politically salient, and recent trends suggest a continued focus on abortion regulation. ${ }^{75}$ How should the General Assembly talk about abortion the next time around?

Our legislators might learn something from the two very different conversations that went on in Richmond last spring. There may be considerable political benefit to inflammatory rhetoric and offhand jokes, to dogmatic and inflexible positions, but they nevertheless come at a cost. By the end of the 2012 General Assembly, very little abortion legislation was signed into law. But

73. Common ground identified by the Common Ground Network for Life \& Choice included: preventing teen pregnancy, making adoption more accessible, avoiding violence and rebuilding community after violence, increasing women's options, reducing circumstances that frequently lead to abortion, and working together in the legislative arena to advance jointly supported measures. See Common Ground Network, supra note 57.

74. In fact, a number of others also have recently advocated for common ground approaches to the abortion debate. See, e.g., Victoria Pynchon, Should We Bother Seeking Common Ground on Abortion?, FORBESWOMAN BLOG (Jan. 16, 2012, 5:43 PM), http:// www.forbes.com/sites/shenegotiates/2012/01/16/should-we-bother-seeking-common-ground -on-abortion/; William Saleton, Abortion Common Ground: A Pro-Choice Agenda, SLATE. COM (Nov. 17, 2010, 7:51 AM), http://www.slate.com/articles/health_and_science/human_ nature/2010/11/abortion_common_ground_a_prochoice_agenda.html (describing lessons drawn from abortion conference at Princeton University's Center for Human Values); Wil. liam Saleton, Abortion Common Ground: A Pro-Choice Agenda. SLATE.COM (Nov. 16, 2010, 7:59 AM), http://www.slate.com/articles/health_and_science/human_nature/2010/11/abort ion_common_ground_a_prolife_agenda.html (same).

75. See State Policy Trends, supra note 2. 
the damage to Virginia's image, and to our regard for one another, was manifest.

In contrast, moving toward a common ground approach just might move the debate forward-toward legislation that transcends polarized positions, and instead advances shared goals and values. And that ought to be something all Virginians can get behind. 